\title{
A comparative study of the effectiveness of some herbs and medicinal plants in therapy obesity in experimental rats
}

\author{
El-Sayeda, G. E. El-Sahar \\ Home Economic Department. Faculty of Specific Education, Ain Shams \\ University, Cairo, Egypt.
}

\section{INTRODUCTION}

Obesity is considered a big problem that has a great effect on health and production. Approximately 2.1 billion people in the world suffer from obesity. Over 3 million of world populations every year die from obesity. The obesity rate in Egypt raised 32\% in recent world population review. In Egypt, alternative treatments are common, especially so-called "remedies". There are many recipes and herbs using in the treatment of obesity and overweight. For example, Mallow (Malva parviflora) a plant widely used in traditional medicine in America and Africa has hypoglycemic, anti-inflammatory, and anti-oxidant effects (Perez and Gutierrez2012) and (Bouriche et al., 2014).

Rosa (2012) reported that the hexane extract of M. Parviflora leaves can efficiently inhibit insulin resistance, oxidative stress, lipid abnormalities and safe hepatic enzymes. As well as, Abdalla et al., (2016) determine the nutritive value of the Jew's mallow (Corchorusolitorius L.) and mallow (Malva parviflora $L$.). The results indicated that the raw and cooked leaves of mallow (on a dry weight basis) contained high crude protein in a range of (36.73$44.77 \%)$, crude fibers (9.81-12.73\%) and total ash content (9.30-16.85\%), but low in crude fat (1.05-3.39\%). The values of energy ranged between 259.7 and $285.29 \mathrm{k} \mathrm{cal} / 100 \mathrm{~g}$. The raw and cooked leaves had a high content of total dietary fiber (32.74-41.45\%), insoluble dietary fiber $(26.10-32.51 \%)$, soluble dietary fiber $(6.64-8.94 \%)$. The neutral detergent fiber was in the range of (20.94 to $28.98 \%$ ), acid detergent fiber (16.97-25.61\%) and acid detergent lignin (7.00-8.93\%).

Also, the common plant people used to apply to treat overweight is Senna. FDA is approved using the Senna (Senna acutifolia) as a laxative. It is used to remedy constipation and also to clear the gut before diagnostic tests such as colonoscopy. (International Legume Database and Information Service, ILDIS, 2005). Senna leaves are widely consumed as tea to treat constipation or to help in weight loss (Sait and Yeong, 2015).Posadzkiin 2013 and Ulbricht et al. in 2011 reported a laxative effect of senna sides. In addition, possibly to cause constipation.

Kerim et al. (2017) indicated that Cassia acutifolia has anti-hyperglycemic effects in obese diabetic rats. The third plant common use in recipes to treat 
obesity is Solenostemma argel. The leaves argel is used in folkloric medicine against a wide range of diseases and health problems. S. argel was registered that contains a good value of nutrients including flavonoids, kaempferol, flavonols, flavanones, chalcones, quercetin, rutin, and alkaloids (Kamel, 2003). Taj Eldeenand Al-Naqeeb (2014) illustrated that Argel methanolic extract display antioxidant and hypoglycemic effect without appearance any toxic effect. Therefore Shayoub et al., (2013) finding that the different types of Solenostemma argel (extracts or leaves) showed potential therapeutic effectiveness (71\%-100\%) and a great margin of safety (98\%-100\%).

White tea is the fourth herb used in formula prepared in our study. Tea is one of the most widely consumed hot beverages in the world. White tea may refer to young or minimally processed leaves of the Camellia sinensis plant. The main constituents of white tea include proteins, polysaccharides, minerals, polyphenols and trace elements, lignins and methylxanthines (caffeine, theophylline, theobromine) (Seeram et al., 2006) and (Moderno et al.,2009).

Like green tea, white tea (Camellia Sinensis) has been popularly used for the reduced weight for different countries. The white tea is non-fermented tea several studies reported that the main active compound in white tea is the Epigallo catechingallate that has beneficial properties. (Phung, 2010; Lambert, 2009 and Nomura, 2008). Lílianet al., (2012) illustrated that white tea supplementation reduced serum triacylglycerols associated with increased total lipids. White tea supplementation also reduced oxidative stress in the liver and adipose.

The present investigation aims to determine i) the effect of using a mixture of natural herbs (Mallow, white tea, argel and Senna) on weight loss in obese rats, ii) the effect of using a mixture of natural herbs aqueous extract (Mallow, white tea, argel and Senna) on weight loss in obese rats, and comparing between them.

\section{Materials and methods}

\section{Animals protocols}

Thirty male Sprague Dawley rats, weighing 110-120 g were used in this study. They were obtained from the National Research Center (NRC) Dokki Giza Egypt. Animals were clinically healthy and they randomized and housed in stainless steel wire bottom cages ( 3 rats /cage) and maintained in an airconditioned room on a $12 \mathrm{~h} \mathrm{light/} \mathrm{dark} \mathrm{cycle} \mathrm{at} 22+2{ }^{\circ} \mathrm{C}$ and given the basal diet for one week as an adaptation period before treatments.

\section{Preparation of mixture herbs}

Mallow (Malvaparviflora), Senna (Cassia angustifolia), white tea (Camellia Sinensis) and argel (Solenostemma acutum L.) were obtained about dried leaves from the local market then mixed together to constitution mixture each 100g contain: $25 \mathrm{~g}$ Mallow, $25 \mathrm{~g}$ Sage and $25 \mathrm{~g}$ white tea and argel. 


\section{Preparation of extract:}

The extract was freshly prepared by taking $1 \mathrm{~g}$ and $2 \mathrm{~g}$ from the mixture and put in a cup then added $100 \mathrm{ml}$ of boiling water. For preparation two concentrations of aqueous extract taken orally 100 and $200 \mathrm{mg} / \mathrm{kg}$ rat/ day.

Induction of obesity: Induction of obesity was induced by feeding the rats on basal diets supplemented with $10 \%$ animal fat. Tallow was purchased from the local market, then grounded before mixing with the diet and added to the basal diet.

\section{Experimental design}

The animals were distributed into two main groups, the first, negative control group Co. (-) $(\mathrm{n}=5)$, fed basal diet, The basal diet composed of casein $(12 \%)$, cellulose (5\%), vitamins mixture (1\%), salts mixture (4\%), corn oil (5\%) and corn starch $(73 \%)$. The basal diet formulation was performed according to A.O.A.C (2006).

The second group ( $\mathrm{n}=25$ ) fed high- fat diet (containing basal diet $+10 \%$ tallow $+1 \%$ cholesterol $+0.02 \%$ bile salt). To reach a weight of $225 \mathrm{~g}$ to $240 \mathrm{~g}$ and it took about two months to get obesity rats. This group was divided into subgroups: group positive control co. $(+)(n=5)$ fed high-fat diet (10\% fat) plus basal diet, the left of subgroups divided into two sections each section two groups:

Section 1: Group $1(\mathrm{G}(1))(\mathrm{n}=5)$ fed high-fat diet plus 5\%mixture herbs. Group $2(\mathrm{G}(2)(\mathrm{n}=5)$ fed a high-fat diet plus $10 \%$ mixture herbs.

Section 2: Group 3 (G (3) (n=5) fed a high-fat diet plus taken orally 100 and $200 \mathrm{mg} / \mathrm{kg}$ rat/ day from their extract were taken orally.

\section{Used chemicals}

Cholesterol as pure white crystalline powder and bile salts as a pure yellow powder were obtained from Elgamhoria Company for Med Preparations Chemicals and Medical Equipment's, Cairo -Egypt.

Kits for determination of the parameters were purchased from Sigma-Aldrich Corp., MO, USA, for use in the analysis at King Abdul-Aziz Chemistry Lab., Medical Research Center.

\section{Biological evaluation}

During the experimental period ( 8 weeks), the diet consumed was recorded every day. The body weight gain (B.W.G \%) and feed efficiency ratio (F.E.R.) were determined according to Chapman et al. (1959).

At the end of the experiment period after 8 weeks, animals were sacrificed after $12 \mathrm{~h}$ of fasting then blood samples were collected with care to avoid hemolysis by receiving it on the wall of the tube. Blood samples were collected in clean dry labeled centrifuge tubes and left to clot at room temperature for a while, then centrifuged at $3000 \mathrm{rpm}$ for 10 minutes. The clear supernatant serums were aspirated by means of Pasteur pipette and stored at $-20^{\circ} \mathrm{C}$ in 
Epindorff's tubes until used in the biochemical analysis (Drury and Wallington, 1980). Serum total cholesterol (TC), triglycerides (TG), highdensity lipoprotein cholesterol (HDL-C) and low-density lipoprotein cholesterol (LDL-C) were determined by using enzymatic colorimetric method (NIHP, 1987; Young and pester, 1975; Fendewaid, 1972; Gordon and Amer, 1977; Lee and Nieman, 1996), respectively. Liver function as Alanine (ALT) and Aspartate (AST) transaminoferase were determined according to the method described by Reitman and Frankel (1957). Alkaline phosphates activity (ALK) was determined using a modified kinetic method of Belfied and Goldberg (1971).

Kidney function as uric acid, albumin, creatinine, urea, and total protein was estimated according to the method described by Barham and Trider (1972), George (2009), Schirmeister (1964) and Patton and Crouch (1977) and Bjorston et al. (2007), respectively. Moreover, total bilirubin is assessed using caffeine benzoate to split bilirubin from the unconjugated bilirubin protein complex according to Vinchi et al. (2008) and also serum glucose was determined according to Tietz (1986).

\section{Sample preparation:}

The post-mortem examination was done as soon as possible and the organ as liver, kidney and heart were collected. Fixation was done in $10 \%$ natural formalin dehydrated cleared and ended paraffin then sectioned at $7 \mu \mathrm{m}$ and stained with harries hematoxylin and eosin for histopathological examination (Carleon, 1967).

\section{Statistical Analysis}

Statistical Analysis was performed by using the computer program, Statistical Package for Social Sciences (SPSS, 1998). Values are given as means \pm SD, and the differences between groups were determined by one way ANOVA. Values of $P<0.05$ were considered significant. 


\section{RESULTS AND DISCUSSION}

\section{1-Effect of mixture herbs on body weight gain, food intake and feed efficiency rate:}

As shown in Table (1) at the end of the experimental period 8 weeks the mean value of final body weight (FBW) in group Co. (+) $(272.40 \pm 21.28 \mathrm{~g})$ was significantly ( $p>0.05)$ higher when compared with the corresponding mean values of groups Co. (-), G 1, G 2, G3 and G4 (170.40 \pm 10.41, $182.80 \pm 12.81$, $180.60 \pm 11.83,170.40 \pm 10.27$ and $168.00 \pm 9.79$ respectively). The mean values of body weight gain (BWG) and feed efficiency ratio (FIR) in groups Co. (-), G 1, G 2, G3 and G4 had significant decrease when compared with group Co.(+), while G (3 and 4) showed highest significant decrease compared to group Co (-) and Co.(+). The herbal mixture has proven highly effective in reducing body weight and treating obesity and thus protection from it's harm especially in groups rats that took the mixture as an aqueous oral extract. Obesity is a metabolic disorder resulting from imbalance between metabolizable energy intake and expenditure (Larsson et al., 1981 and Hartz et al., 1983).

On the other hand, Bach et al. (1996), Pellizzon et al. (2002) and Murase et al. (2002), reported that the body has a limited ability to oxidize excess lipids, and a high-fat intake contributes to the development of obesity in both humans and rodents. This variation may be that these herbal leaves had contained polyphenols and dietary fiber in the diet for healthy eating and were taken orally from their extract, which may help to prevent obesity and to maintain ideal body weight. Phenolic acids and flavonoids compounds have been found to have a useful influence on obesity. Illustrating, dietary natural antioxidants as polyphenols were a regulator for adipocyte metabolism to prevent the growth of adipose tissue (Badimon et al., 2010). These results agreed with observed by (EL-Sahar, 2012) ${ }^{\mathbf{1}}$ who registered that total loss weight was $8.9 \mathrm{~kg}$ in human who received 3 cups per day from mixture consisted of $M$. parviflora (25\%), sage (50\%) and Senna (25\%) at the end of the experiment after six weeks.

These results were agreement with the results reported by (Robert, et al., 2004) revealed that country mallow from common dietary supplements used for weight loss, which increase energy expenditure. This result may be due to the mallow leaf extracts possess anti-inflammatory and antioxidant activities (Bouriche et al., 2014). The decrease in body weight was gradually but not suddenly during the three time intervals. $M$. parviflora ethanolic extract was 
more effective in weight loss compared with $M$. parviflora water extract (ELSahar, 2012) ${ }^{2}$.

This effect was explained by Grela (2000) and Schone et al. (2006) who stated that the herbal slimmer generally work as metabolism boosters, fat burners, appetite suppressants and diuretics which eliminate excess water and laxatives, which expel waste and detoxify the digestive system so that our bodies use nutrients more efficiently and therefore store less fat. In addition, the herbal mixture formulation contains antioxidants in mallow, stimulant laxatives that are present in senna. The HFD feeding successfully induced obesity in the rats, as evidenced by a significance increment of body weight (1 01.63\%) compared to normal group in agreement with data previously reported by Abdel-Sattar et al., (2018) and Tunapong et al., 2018). While, $S$. argel extract and fractions efficiently reduced body weight in a short period of time which qualifies the plant as a promising natural product to be used in weight control (El-Shiekh et al., 2018).

Table (1): Body weight gain, food intake and feed efficiency ratio after 8weeks feeding.

\begin{tabular}{|c|c|c|c|c|c|}
\hline & IBW(g) & FBW(g) & BWG (g) & FI(g) & FER\% \\
\hline & Mean \pm SD & Mean \pm SD & Mean \pm SD & Mean \pm SD & Mean \pm SD \\
\hline Co.(-) & $149.00 \mathrm{~b} \pm 12.30$ & $170.40 \mathrm{c} \pm 10.41$ & $21.4 \mathrm{~b} \pm 2.53$ & $23.52 \mathrm{c} \pm 1.12$ & $0.91 \mathrm{~b} \pm 0.09$ \\
\hline Co. $(+)$ & $229.80 \mathrm{a} \pm 14.33$ & $272.40 \mathrm{a} \pm 21.28$ & $42.6 \mathrm{a} \pm 4.23$ & $31.42 \mathrm{a} \pm 3.24$ & $1.36 \mathrm{a} \pm 0.12$ \\
\hline G1 & $232.00 \mathrm{a} \pm 15.67$ & $182.80 \mathrm{~b} \pm 12.81$ & $-49.2 \mathrm{c} \pm 6.24$ & $28.24 \mathrm{ab} \pm 5.21$ & $-1.74 \mathrm{c} \pm 0.11$ \\
\hline G2 & $234.00 \mathrm{a} \pm 16.58$ & $180.60 \mathrm{~b} \pm 11.83$ & $-53.4 \mathrm{c} \pm 4.52$ & $26.00 \mathrm{~b} \pm 3.01$ & $-2.01 \mathrm{c} \pm 0.21$ \\
\hline G3 & $235.80 \mathrm{a} \pm 17.46$ & $170.40 \mathrm{c} \pm 10.27$ & $-65.4 \mathrm{c} \pm 2.55$ & $23.89 \mathrm{c} \pm 7.21$ & $-2.74 \mathrm{c} \pm 0.14$ \\
\hline G4 & $233.80 \mathrm{a} \pm 15.95$ & $168.00 \mathrm{c} \pm 9.79$ & $-65.8 \mathrm{c} \pm 4.14$ & $22.13 \mathrm{c} \pm 4.57$ & $-2.97 \mathrm{c} \pm 0.09$ \\
\hline F & 146.213 & 276.621 & 22.451 & 27.213 & .045 \\
\hline Sig. & 0.000 & 0.000 & 0.000 & 0.000 & 0.000 \\
\hline
\end{tabular}

Co (-), normal diet; Co (+) obese rat ( high-fat diet); G(1,2,3 and 4), obese rat (high-fat diet plus mixture herbs); IBW, initial body weight; FBW, final body weight; BWG, body weight gain; FI, feed intake; FER, feed efficiency ratio. Values with the same letters by column indicate no significant difference $(\mathrm{p}<0.05)$ and vice versa.

\section{2- Effect of mixture herbs on the relative weight of heart, liver, kidney, spleen and lung:}

In table (2) shows the effect of mixture herbs on relative weight of heart, liver, kidney, spleen and lung, the results showed that there are no significant differences in obese groups (G1, G2, G3 and G4) fed on high-fat diet and mixture of herbs in the relative weight of heart, liver, spleen and lung when compared with control negative and positive group. However relative kidney weight showed a significant decrease in G2 $(0.92 \pm 0.14)$ when compared with control negative and positive group. G3 showed a significant increase when compared with co. $(+)$. These results are confirmed by Nemani et al. (2011) 
reported that significantly higher organ weights of the heart, liver, and kidney, and no different lung weights in the obesity rats.

Table (2): Relative weight of heart, liver, kidney, spleen and lung (g):

\begin{tabular}{|c|c|c|c|c|c|}
\hline & Heart & Liver & Kidney & Spleen & Lung \\
\hline & Mean $\pm \mathrm{SD}$ & Mean $\pm \mathrm{SD}$ & Mean $\pm \mathrm{SD}$ & Mean $\pm \mathrm{SD}$ & Mean $\pm \mathrm{SD}$ \\
\hline $\mathrm{Con}(-)$ & $0.43 \mathrm{a} \pm 0.06$ & $3.45 \mathrm{a} \pm 0.69$ & $1.03 \mathrm{ab} \pm 0.06$ & $0.52 \mathrm{a} \pm 0.16$ & $1.02 \mathrm{a} \pm 0.08$ \\
\hline Con(+) & $0.45 \mathrm{a} \pm 0.06$ & $3.13 \mathrm{a} \pm 0.46$ & $1.00 \mathrm{ab} \pm 0.10$ & $0.52 \mathrm{a} \pm 0.10$ & $1.04 \mathrm{a} \pm 0.11$ \\
\hline $\mathrm{G} 1$ & $0.38 \mathrm{a} \pm 0.07$ & $3.95 \mathrm{a} \pm 1.63$ & $1.02 \mathrm{ab} \pm 0.14$ & $0.65 \mathrm{a} \pm 0.32$ & $0.98 \mathrm{a} \pm 0.10$ \\
\hline $\mathrm{G} 2$ & $0.48 \mathrm{a} \pm 0.09$ & $3.12 \mathrm{a} \pm 0.32$ & $0.92 \mathrm{~b} \pm 0.14$ & $0.48 \mathrm{a} \pm 0.06$ & $0.96 \mathrm{a} \pm 0.18$ \\
\hline $\mathrm{G} 3$ & $0.46 \mathrm{a} \pm 0.06$ & $3.23 \mathrm{a} \pm 0.50$ & $1.09 \mathrm{a} \pm 0.13$ & $0.47 \mathrm{a} \pm 0.12$ & $0.97 \mathrm{a} \pm 0.13$ \\
\hline G4 & $0.44 \mathrm{a} \pm 0.04$ & $3.37 \mathrm{a} \pm 0.58$ & $1.04 \mathrm{ab} \pm 0.08$ & $0.53 \mathrm{a} \pm 0.12$ & $1.10 \mathrm{a} \pm 0.14$ \\
\hline F & 1.248 & 0.727 & 1.230 & 0.754 & 0.853 \\
\hline Sig. & 0.318 & 0.610 & 0.326 & 0.591 & 0.526 \\
\hline
\end{tabular}

Values with the same letters by column indicate no significant difference $(\mathrm{p}<0.05)$ and vice versa.

3- Effect of mixture herbs on serum lipid profile and glucose level in obese rats after 8 weeks:

Lipid profile as triglycerides, total cholesterol, LDL-C, HDL-C and glucose were determined in the obese rat groups fed on different levels from mixture herbs at 10 and $20 \%$ and taken orally at 100 and $200 \mathrm{mg} / \mathrm{kg}$ rat $/$ day from the extract their herbs and the results are reported in Table (3) and table (4). The results showed that groups Co.(-), G1, G2, G3 and G 4 gave significant increase in glucose, total cholesterol, LDL-C and triglycerides levels when compared with negative control group at the beginning of the experiment, however, at the end of the experiment found significant decrease in all experimental groups and negative control group in glucose, total cholesterol, LDL-C and triglycerides levels when compared with positive control group except G3 which had the best significant decrease in triglycerides level.

It was evident that the results after treatment with the herbal mixture were significantly improved at the end of the experiment. It was found that the best moral improvement in glucose, total cholesterol, LDL-C and HDL-C in G4 taken orally the aqueous extract from the herbal mixture at $200 \mathrm{mg} / \mathrm{kg}$ rat/ day. These results are similar with several studies have demonstrated that the uniquely high level of polyphenols in the different herbal may play an important role in contributing to the health benefit such as lowering glucose, LDL cholesterol level, and reducing the risk of cardiovascular diseases (Constantinou et al. 2008). Several clinical and epidemiological studies showed that Hyperlipidemia is being a significant danger factor for chronic heart disease, is dangerous public health trouble in the world (Jaffer et al., 2004). Senna leaves are used as liver activators, anthelmintic, cholagogue, expectorant, and febrifuge. It was beneficial in abdominal disorders, leprosy, 
skin disorders, leucoderma, splenomegaly, hepatomegaly, dyspepsia, cough, and bronchitis (Balasankar et al., 2013).Also, these results confirmed by Farhan et al. (2012) found that the extract of polyphenols from leaves of Malva parviflora contains different amounts of phenols, flavonoid, saponin, alkaloid, resin and tannin. The methanol fraction showed high antioxidant potential. Traditionally Malva parviflora is used for the treatment of inflammation, pain and liver injuries (Afolayan et al., 2010).

This finding was in coincidence with the observation of Perez and Gutierrez (2012) who reported that the effect of hexane $M$. parviflora extract on the total cholesterol level, triglycerides and lipid peroxidation were restored in streptozotocin-induced diabetic rats to nearly normal levels. This effect was explained by Shale et al. (2005) who demonstrated that the variation in the antibacterial and anti-inflammatory activity of different growth forms of mallow (M. parviflora) and guide for support of the anti-inflammatory compounds. In addition, Wang and Bunkers (2000) revealed that the potent heterologous antifungal proteins from cheeseweed (M. parviflora).

Also, EL_Sayeda and abor (2017) were observed that total cholesterol, triglycerides, LDL cholesterol and VLDL-cholesterol levels significantly decreased in all the tested diets compared with diabetic control. There are also reports indicating that drinking tea lowers total cholesterol levels, as well as improves the ratio of good cholesterol (HDL) to bad cholesterol (LDL) (Cheng, 2006). These results confirmed with (Friedman et al, 2005) who reported that Catechins, another group of antioxidants, have been found to reduce cholesterol, and white tea is teeming with them. White tea improves good cholesterol while suppressing bad cholesterol. This helps prevent the hardening of the arteries and blockage of blood flow. Wolever et al. (2003) reported that LDL particle size is reduced and HDL-TG increased in insulin-resistant and diabetic subjects. Also, these results confirmed. One of the proposed mechanisms for the possible protective effect of tea against cardiovascular diseases is the inhibition of the oxidation of LDL (Wiseman et al., 1997). EL_Sayeda and abor (2017) observed that white tea was able to decrease blood glucose concentration in diabetic rats injected with alloxan.

Many known compounds found in. were tea improved insulin with the highest activity due to EGCG followed by ECG, tannins and theaflavins. Caffeine, catechin and EC displayed insignificant insulin-enhancing activities. The addition of lemon to the tea did not affect the insulin-potentiating activity EGCG has been found to increase insulin sensitivity and may repair damaged beta cells (McKay and Blumberg (2002) and Anderson and Polansky (2002)). EL_Sayeda and abor (2017) observed that white tea was able to decrease blood glucose concentration in diabetic rats injected with alloxanin addition to the ethanolic extract of $S$. argel was proved to have strong inhibitory 
activity against pancreatic lipase enzyme (Elbashir et al., 2018). $S$. argel showed a good in-vitro inhibitory activity towards lipase, $\alpha$-glucosidase and $\alpha$ amylase enzymes, in addition to its anti-oxidant power (El-Shiekh et al., 2018). Table (3): Levels of total cholesterol and triglycerides of control and obese rats groups before and after 8 weeks from treated by the herbal mixture.

\begin{tabular}{|c|c|c|c|c|}
\hline & $\begin{array}{c}\text { CH be } \\
(\mathbf{m g} / \mathbf{d l})\end{array}$ & $\begin{array}{c}\text { CH af } \\
(\mathbf{m g} / \mathbf{d l})\end{array}$ & $\begin{array}{c}\text { TG be } \\
(\mathbf{m g} / \mathbf{d l})\end{array}$ & $\begin{array}{c}\text { TG af } \\
(\mathbf{m g} / \mathbf{d l})\end{array}$ \\
\hline & Mean $\pm \mathrm{SD}$ & Mean $\pm \mathrm{SD}$ & Mean $\pm \mathrm{SD}$ & Mean \pm SD \\
\hline Co.(-) & $85.60 \mathrm{~b} \pm 7.16$ & $85.20^{\mathrm{b}} \pm 5.07$ & $69.20 \mathrm{c} \pm 22.51$ & $81.00 \mathrm{bc} \pm 17.38$ \\
\hline Co.(+) & $139.20 \mathrm{a} \pm 23.67$ & $161.40 \mathrm{a} \pm 17.81$ & $98.20 \mathrm{~b} \pm 12.05$ & $92.00 \mathrm{ab} \pm 11.25$ \\
\hline G1 & $142.20 \mathrm{a} \pm 32.87$ & $80.40 \mathrm{bc} \pm 15.73$ & $116.00 \mathrm{ab} \pm 14.90$ & $63.60 \mathrm{~cd} \pm 18.89$ \\
\hline G2 & $142.60 \mathrm{a} \pm 16.47$ & $72.60 \mathrm{bc} \pm 14.29$ & $113.60 \mathrm{~b} \pm 12.78$ & $51.80 \mathrm{~d} \pm 17.46$ \\
\hline G3 & $120.60 \mathrm{a} \pm 14.28$ & $74.40 \mathrm{bc} \pm 2.70$ & $138.80 \mathrm{a} \pm 24.19$ & $107.60 \mathrm{a} \pm 25.96$ \\
\hline G4 & $149.80 \mathrm{a} \pm 20.33$ & $65.80 \mathrm{c} \pm 10.64$ & $107.60 \mathrm{~b} \pm 17.85$ & $60.00 \mathrm{~cd} \pm 11.92$ \\
\hline F & 6.614 & 41.601 & 8.166 & 7.162 \\
\hline Sig. & 0.001 & 0.000 & 0.000 & 0.000 \\
\hline
\end{tabular}

Values with the same letters by column indicate no significant difference $(\mathrm{p}<0.05)$ and vice versa.

Table (4): Levels of HDL-C, LDL-C and glucose of control and obese rats groups before and after 8 weeks from treated by herbal mixture:

\begin{tabular}{|c|c|c|c|c|c|c|}
\hline & $\begin{array}{c}\text { HDL be } \\
(\mathbf{m g} / \mathbf{d l})\end{array}$ & $\begin{array}{c}\text { HDL af } \\
(\mathbf{m g} / \mathbf{d l})\end{array}$ & $\begin{array}{c}\text { LDL be } \\
(\mathbf{m g} / \mathbf{d l})\end{array}$ & $\begin{array}{c}\text { LDL af } \\
(\mathbf{m g} / \mathbf{d l})\end{array}$ & $\begin{array}{c}\text { Glu be } \\
(\mathbf{m g} / \mathbf{d l})\end{array}$ & $\begin{array}{c}\text { Gluaf } \\
(\mathbf{m g} / \mathbf{d l})\end{array}$ \\
\hline & Mean $\pm \mathrm{SD}$ & Mean $\pm \mathrm{SD}$ & Mean $\pm \mathrm{SD}$ & Mean $\pm \mathrm{SD}$ & Mean $\pm \mathrm{SD}$ & $\mathrm{Mean} \pm \mathrm{SD}$ \\
\hline Con(-) & $41.20 \mathrm{a} \pm 7.50$ & $35.00 \mathrm{~b} \pm 5.43$ & $61.60 \mathrm{~b} \pm 13.67$ & $38.20 \mathrm{bc} \pm 11.90$ & $71.20 \mathrm{~b} \pm 2.77$ & $75.00 \mathrm{bc} \pm 9.59$ \\
\hline Con(+) & $40.20 \mathrm{a} \pm 3.56$ & $42.20 \mathrm{ab} \pm 16.75$ & $120.60 \mathrm{a} \pm 18.08$ & $144.80 \mathrm{a} \pm 17.50$ & $127.20 \mathrm{a} \pm 5.17$ & $139.00 \mathrm{a} \pm 2.92$ \\
\hline G1 & $36.60 \mathrm{a} \pm 19.60$ & $52.20 \mathrm{a} \pm 4.02$ & $126.60 \mathrm{a} \pm 6.95$ & $56.40 \mathrm{~b} \pm 19.41$ & $130.00 \mathrm{a} \pm 8.60$ & $80.40 \mathrm{~b} \pm 6.58$ \\
\hline G2 & $33.40 \mathrm{a} \pm 10.74$ & $47.40 \mathrm{a} \pm 5.77$ & $121.80 \mathrm{a} \pm 5.54$ & $27.20 \mathrm{c} \pm 10.31$ & $134.20 \mathrm{a} \pm 7.85$ & $75.00 \mathrm{bc} \pm 5.39$ \\
\hline G3 & $40.20 \mathrm{a} \pm 2.17$ & $47.20 \mathrm{a} \pm 7.79$ & $139.00 \mathrm{a} \pm 16.42$ & $54.60 \mathrm{~b} \pm 12.58$ & $133.20 \mathrm{a} \pm 8.04$ & $78.40 \mathrm{bc} \pm 6.31$ \\
\hline G4 & $41.40 \mathrm{a} \pm 8.08$ & $52.60 \mathrm{a} \pm 3.44$ & $133.60 \mathrm{a} \pm 15.82$ & $37.60 \mathrm{bc} \pm 7.09$ & $135.40 \mathrm{a} \pm 6.99$ & $70.40 \mathrm{c} \pm 2.07$ \\
\hline F & 0.474 & 2.896 & 21.341 & 48.894 & 66.123 & 93.573 \\
\hline Sig. & 0.792 & 0.035 & 0.000 & 0.000 & 0.000 & 0.000 \\
\hline
\end{tabular}

Values with the same letters by column indicate no significant difference $(\mathrm{p}<0.05)$ and vice versa.

4- Effect of mixture herbs on liver function in obese rats groups before and after 8 weeks from treated by an herbal mixture:

In table (5) illustrated that liver function ALT, AST and ALK in the obesity rat groups fed on a different diet from mixture herbs at 10 and $20 \%$ level and taken orally at 100 and $200 \mathrm{mg} / \mathrm{kg}$ rat/ day from the extract their herbs, at the beginning of the experiment the results showed that ALT, AST and ALK in G1, G2 and G3 had significant difference when compared with negative control group. However, the level of ALT in G1, G2, G3 and G4 had significantly improved when compared with the positive and negative control group.

It was also, found a significant improvement in AST in groups G1 and G2, ALK had significantly improved in groups G1, G2 and G3. This result indicated that these herbs were safe and had a good effect on liver function. Pharmacological studies have shown that $M$. parviflora possesses anti diabetic, 
antibacterial, antifungal, hepatoprotective, anti-irritant, antioxidant, neuroprotective, analgesic, anti-ulcerogenic, and other activities. It is well known that $M$. parviflora has been the main source of natural antioxidants. $M$. parviflora contains flavonoids and phenolic compounds (Ajeet S., 2017).

El-Sahar $(\mathbf{2 0 1 2})^{2}$ has been found that serum total protein, globulin, AST and ALT levels were improved by administering $M$. parviflora leaves ethanolic extract followed by $M$. parviflora leaves water extract orally to aged rats which indicate an improvement in liver functions. This finding was in coincidence with the observation of Perez and Gutierrez (2012) who observed that the hexane $M$. parviflora extract on the liver function, liver and muscle glycogen glucose-6-phosphatase, glucokinase and hexokinase activities were restored in streptozotocin-induced diabetic rats to nearly normal levels. The increase of the activity of liver enzymes in serum is mainly due to the leakage of these enzymes from the liver cytosol into the blood stream as mentioned by Mansour et al., (2002).

In addition, Milagro et al., (2006) reported that, a link among increased fat depots, insulin resistance, and liver oxidative stress. Thus, liver oxidative stress probably contributes to hepatic disorders and aggravates metabolic syndrome.The administration of tea polyphenols and tea pigments in drinking water caused a decrease in the number and area of GST-P-positive foci in liver rats (Jia et al., 2002).

Table (5): Levels of liver function of control and obese rats groups before and after 8 weeks from treated by the herbal mixture:

\begin{tabular}{|c|c|c|c|c|c|c|}
\hline & $\begin{array}{c}\text { ALT be } \\
(\boldsymbol{\mu} / \mathbf{m l})\end{array}$ & $\begin{array}{c}\text { ALT af } \\
(\boldsymbol{\mu} / \mathbf{m l})\end{array}$ & $\begin{array}{c}\text { AST be } \\
(\boldsymbol{\mu} / \mathbf{m l})\end{array}$ & $\begin{array}{c}\text { AST af } \\
(\boldsymbol{\mu} / \mathbf{m l})\end{array}$ & $\begin{array}{c}\text { ALK be } \\
(\boldsymbol{\mu} / \mathbf{m l})\end{array}$ & $\begin{array}{c}\text { ALK af } \\
(\boldsymbol{\mu} / \mathbf{m l})\end{array}$ \\
\hline & Mean $\pm \mathrm{SD}$ & Mean $\pm \mathrm{SD}$ & Mean $\pm \mathrm{SD}$ & Mean $\pm \mathrm{SD}$ & Mean $\pm \mathrm{SD}$ & Mean $\pm \mathrm{SD}$ \\
\hline Con(-) & $63.40 \mathrm{a} \pm 24.42$ & $53.20 \mathrm{a} \pm 21.57$ & $10.00 \mathrm{a} \pm 2.00$ & $9.60 \mathrm{a} \pm 2.19$ & $34.20 \mathrm{~b} \pm 7.33$ & $38.80 \mathrm{a} \pm 5.63$ \\
\hline Con(+) & $46.80 \mathrm{ab} \pm 8.70$ & $48.40 \mathrm{a} \pm 4.28$ & $9.00 \mathrm{a} \pm 1.41$ & $9.80 \mathrm{a} \pm 4.02$ & $42.80 \mathrm{a} \pm 5.36$ & $41.40 \mathrm{a} \pm 2.07$ \\
\hline G1 & $40.40 \mathrm{~b} \pm 8.73$ & $30.40 \mathrm{~b} \pm 16.61$ & $11.00 \mathrm{a} \pm 2.24$ & $8.00 \mathrm{a} \pm 2.45$ & $42.00 \mathrm{ab} \pm 4.85$ & $39.80 \mathrm{a} \pm 4.76$ \\
\hline G2 & $47.20 \mathrm{ab} \pm 8.14$ & $15.40 \mathrm{~b} \pm 2.51$ & $11.60 \mathrm{a} \pm 3.71$ & $8.00 \mathrm{a} \pm 2.83$ & $43.40 \mathrm{a} \pm 4.62$ & $40.40 \mathrm{a} \pm 5.77$ \\
\hline G3 & $58.20 \mathrm{ab} \pm 20.51$ & $29.80 \mathrm{~b} \pm 7.12$ & $12.40 \mathrm{a} \pm 56.80$ & $11.60 \mathrm{a} \pm 0.89$ & $41.40 \mathrm{ab} \pm 7.99$ & $39.60 \mathrm{a} \pm 2.30$ \\
\hline G4 & $63.20 \mathrm{a} \pm 10.87$ & $19.20 \mathrm{~b} \pm 7.76$ & $10.60 \mathrm{a} \pm 6.47$ & $10.00 \mathrm{a} \pm 2.00$ & $37.40 \mathrm{ab} \pm 3.85$ & $40.20 \mathrm{a} \pm 1.79$ \\
\hline F & 2.083 & 7.954 & 0.336 & 1.396 & 1.910 & 0.734 \\
\hline Sig. & 0.103 & 0.000 & 0.886 & 0.261 & 0.130 & 0.605 \\
\hline
\end{tabular}

Values with the same letters by column indicate no significant difference $(\mathrm{p}<0.05)$ and vice versa.

5-Effect of mixture herbs on kidney function ( $T$. protein, albumin and bilirubin) in obese rats groups before and after 8 weeks from treated by herbal mixture:

In the table (6) the results showed that there was no significant difference in total protein and bilirubin in G1, G2, G3 and G4 when compared with control negative and positive groups at the beginning of the experiment. However, at the end of the experiment, total protein in G1, G2, G3 and G4 had a significant 
increase at $(\mathrm{p}<0.05)$ when compared with control negative and positive groups, but there were no significant differences in experimental groups in albumin and bilirubin. Low serum albumin, then, mark poor liver function (Naganna, 1989). The different rat groups were fed on the mixture from mallow (Malvapa rviflora), white tea, argel and senna (Cassia angustifolia) the results showed that improvement of kidney functions and confirmed improvement of the liver function too due to these herbs had contained rich amounts polyphenolic, minerals, fiber, and total carbohydrates. Therefore it can be concluded that the anti-obesity action of argel could be attributed to multiple mechanisms including hypolipidemic, enhanced lipolysis, hypoglycemic and adipokines modulating power, as well as, anti-inflammatory, decreased lipogenesis, increased fatty acid oxidation and appetite suppression actions. These results provided scientific evidence to the use of $S$. argel in controlling weight gain.

Table (6): Levels of kidney function (total protein, albumin and bilirubin) of control and obesity rats groups before and after 8 weeks from treated by herbal mixture.

\begin{tabular}{|c|c|c|c|c|c|c|}
\hline & $\begin{array}{c}\text { T.P be } \\
(\mathbf{m g} / \mathbf{d l})\end{array}$ & $\begin{array}{c}\text { T.P af } \\
(\mathbf{m g} / \mathbf{d l})\end{array}$ & $\begin{array}{c}\text { ALB be } \\
(\mathbf{m g} / \mathbf{d l})\end{array}$ & $\begin{array}{c}\text { ALB af } \\
(\mathbf{m g} / \mathbf{d l})\end{array}$ & $\begin{array}{c}\text { BIL be } \\
(\mathbf{m g} / \mathbf{d l})\end{array}$ & $\begin{array}{c}\text { BIL af } \\
(\mathbf{m g} / \mathbf{d l})\end{array}$ \\
\hline & Mean $\pm \mathrm{SD}$ & Mean $\pm \mathrm{SD}$ & Mean \pm SD & Mean \pm SD & Mean \pm SD & Mean \pm SD \\
\hline Con(-) & $4.12 \mathrm{a} \pm 2.55$ & $5.34 \mathrm{~b} \pm 2.08$ & $2.70 \mathrm{c} \pm 0.51$ & $4.16 \mathrm{a} \pm 0.34$ & $0.36 \mathrm{a} \pm 0.29$ & $0.55 \mathrm{a} \pm 0.08$ \\
\hline Con(+) & $3.82 \mathrm{a} \pm 1.86$ & $7.30 \mathrm{ab} \pm 2.33$ & $4.24 \mathrm{a} \pm 0.63$ & $3.96 \mathrm{a} \pm 0.45$ & $0.52 \mathrm{a} \pm 0.07$ & $0.51 \mathrm{a} \pm 0.02$ \\
\hline G1 & $3.50 \mathrm{a} \pm 2.61$ & $9.18 \mathrm{a} \pm 1.99$ & $3.10 \mathrm{bc} \pm 0.74$ & $2.24 \mathrm{~b} \pm 1.11$ & $0.48 \mathrm{a} \pm 0.05$ & $8.49 \mathrm{a} \pm 18.18$ \\
\hline G2 & $5.02 \mathrm{a} \pm 3.43$ & $9.14 \mathrm{a} \pm 1.78$ & $3.38 \mathrm{bc} \pm 0.61$ & $4.02 \mathrm{a} \pm 0.23$ & $0.51 \mathrm{a} \pm 0.05$ & $0.45 \mathrm{a} \pm 0.09$ \\
\hline G3 & $4.00 \mathrm{a} \pm 2.44$ & $8.00 \mathrm{a} \pm 1.64$ & $3.40 \mathrm{bc} \pm 0.45$ & $3.98 \mathrm{a} \pm 0.62$ & $0.48 \mathrm{a} \pm 0.04$ & $0.45 \mathrm{a} \pm 0.08$ \\
\hline G4 & $6.74 \mathrm{a} \pm 2.99$ & $7.48 \mathrm{ab} \pm 0.58$ & $3.86 \mathrm{ab} \pm 0.37$ & $3.98 \mathrm{a} \pm 0.16$ & $0.49 \mathrm{a} \pm 0.06$ & $0.38 \mathrm{a} \pm 0.04$ \\
\hline F & 0.987 & 3.057 & 4.656 & 7.960 & 0.944 & 0.973 \\
\hline Sig. & 0.446 & 0.028 & 0.004 & 0.000 & 0.471 & 0.454 \\
\hline
\end{tabular}

Values with the same letters by column indicate no significant difference $(\mathrm{p}<0.05)$ and vice versa.

6-Effect of mixture herbs on kidney function (Creatinine, urea and uric acid) in obese rats groups before and after 8 weeks from treated by herbal mixture:

The results in table (7) showed that there was no significant difference in creatinine level before and after treatment. However, urea gave a significant increase in G1, G2 and G4 when compared with control negative and positive groups at the beginning of the experiment, a similar result found in uric acid. But, at the end of the experiment uric acid showed a significant increase inG1, $\mathrm{G} 2, \mathrm{G} 3$ and $\mathrm{G} 4$ at $(\mathrm{p} \leq 0.01)$ when compared with control negative and positive groups. Also, there was a clear decrease in all groups except G1 and negative control group between before and after treatment, there was also improvement in G2, G3 and G4 compared with the negative control. This result means this herb's efficacy and safety on kidney function. 
This result agreed with EL- Sayeda and Abor (2017) who indicated that with all experimental groups administrated bread fortified with white tea gave a significant decrease in uric acid and urea nitrogen. The increase in these parameters means the disorder in kidney functions. These results confirmed by Cameron and Greger (1998) who found that the serum urea is an important test for knowing the conditions of the kidneys; therefore the increase in the urea level may indicate impairment of renal.

Table (7): Levels of kidney function (Creatinine, Urea, and Uric acid) of control and obese rats groups before and after 8 weeks from treated by herbal mixture.

\begin{tabular}{|c|c|c|c|c|c|c|}
\hline & $\begin{array}{c}\text { Creat. Be } \\
(\mathbf{m g} / \mathbf{d l})\end{array}$ & $\begin{array}{c}\text { Creat. Af } \\
(\mathbf{m g} / \mathbf{d l})\end{array}$ & $\begin{array}{c}\text { Urea be } \\
(\mathbf{m g} / \mathbf{d l})\end{array}$ & $\begin{array}{c}\text { Urea af } \\
(\mathbf{m g} / \mathbf{d l})\end{array}$ & $\begin{array}{c}\text { U.A be } \\
(\mathbf{m g} / \mathbf{d l})\end{array}$ & $\begin{array}{c}\text { U.A af } \\
(\mathbf{m g} / \mathbf{d l})\end{array}$ \\
\hline & Mean $\pm \mathrm{SD}$ & Mean $\pm \mathrm{SD}$ & Mean $\pm \mathrm{SD}$ & Mean $\pm \mathrm{SD}$ & Mean $\pm \mathrm{SD}$ & Mean $\pm \mathrm{SD}$ \\
\hline Con$(-)$ & $0.55 \mathrm{a} \pm 0.20$ & $0.94 \mathrm{~b} \pm 0.11$ & $17.20 \mathrm{ab} \pm 6.65$ & $21.60 \mathrm{~cd} \pm 7.54$ & $2.70 \mathrm{~b} \pm 0.60$ & $2.42 \mathrm{~b} \pm 0.37$ \\
\hline Con$(+)$ & $0.63 \mathrm{a} \pm 0.12$ & $1.08 \mathrm{~b} \pm 0.30$ & $19.40 \mathrm{ab} \pm 2.88$ & $16.60 \mathrm{~d} \pm 4.77$ & $5.76 \mathrm{a} \pm 2.67$ & $1.82 \mathrm{~b} \pm 0.61$ \\
\hline G1 & $0.69 \mathrm{a} \pm 0.24$ & $0.95 \mathrm{~b} \pm 0.05$ & $22.40 \mathrm{ab} \pm 4.93$ & $40.20 \mathrm{a} \pm 7.82$ & $3.56 \mathrm{~b} \pm 0.49$ & $3.44 \mathrm{a} \pm 1.44$ \\
\hline G2 & $0.62 \mathrm{a} \pm 0.15$ & $1.59 \mathrm{a} \pm 0.70$ & $24.20 \mathrm{a} \pm 6.30$ & $35.60 \mathrm{ab} \pm 9.71$ & $4.40 \mathrm{ab} \pm 1.49$ & $1.58 \mathrm{~b} \pm 0.37$ \\
\hline G3 & $0.64 \mathrm{a} \pm 0.21$ & $0.96 \mathrm{~b} \pm 0.30$ & $16.80 \mathrm{~b} \pm 2.59$ & $43.80 \mathrm{a} \pm 8.23$ & $5.60 \mathrm{a} \pm 0.81$ & $1.94 \mathrm{~b} \pm 0.47$ \\
\hline G4 & $0.51 \mathrm{a} \pm 0.07$ & $0.78 \mathrm{~b} \pm 0.26$ & $18.60 \mathrm{ab} \pm 4.28$ & $29.40 \mathrm{bc} \pm 4.34$ & $3.96 \mathrm{ab} \pm 0.86$ & $1.94 \mathrm{~b} \pm 0.49$ \\
\hline F & 0.788 & 3.160 & 1.843 & 10.591 & 3.737 & 4.251 \\
\hline Sig. & 0.569 & 0.025 & 0.142 & 0.000 & 0.012 & 0.007 \\
\hline
\end{tabular}

Values with the same letters by column indicate no significant difference $(\mathrm{p}<0.05)$ and vice versa.

\section{Histopathological effects:}

\section{1-Morphologic changes of rat heart stained with hematoxylin and eosin:}

Representative heart sections stained with hematoxylin and eosin in each group are shown in Figure (1:6) the heart in the control rat of group Co. (-) (Fig. 1) showed normal cardiac myocyte. On the other hand Fig. 2 group co $(+)$ showing cardiac mononuclear cells infiltration between cardiac myocytes. However, Fig. (3) Heart of rat from group 1 showing intermuscular oedema. Also, Fig. (4 and 5) heart of rat from group 2, 3 showing no histopathological changes as similar results for group Co. (-) which indicated a similar preventive effect of mixture herb in this experimental model. But, Fig. (6) Heart of rat from group 4 showing intermuscular oedema.

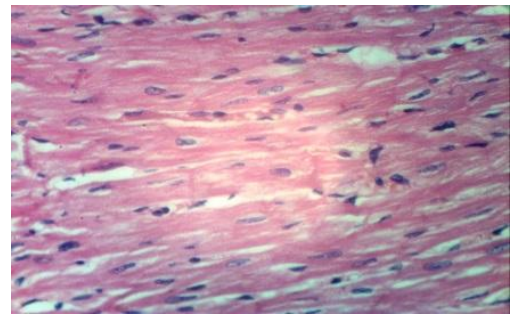

Fig. (1): Heart of rat from group Co (-) Showing normal myocytes.

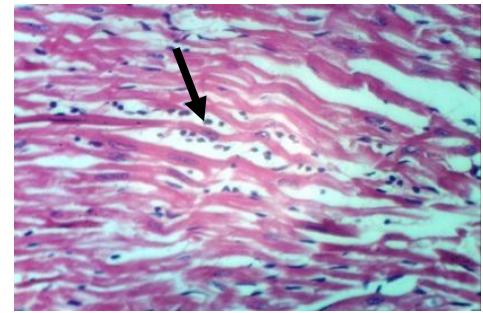

Fig. (2): Heart of rat from group co (+) showing cardiac mononuclear cells infiltration between cardiac myocytes 


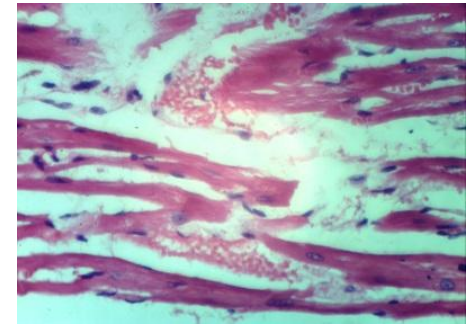

Fig. (3): Heart of rat from group 1 showing intermuscula roedema.

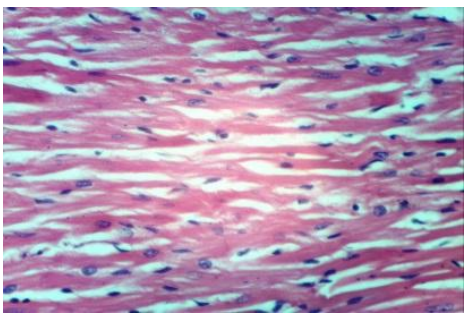

Fig. (5): Heart of rat from group 3 showing no histopathological changes.

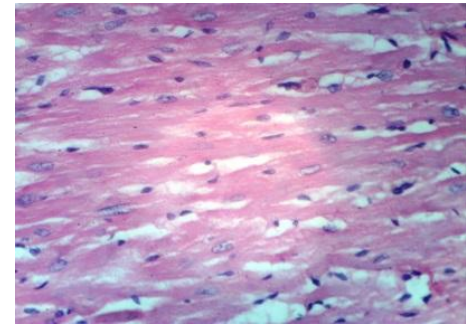

Fig. (4): Heart of rat from group 2 showing no histopathological changes.

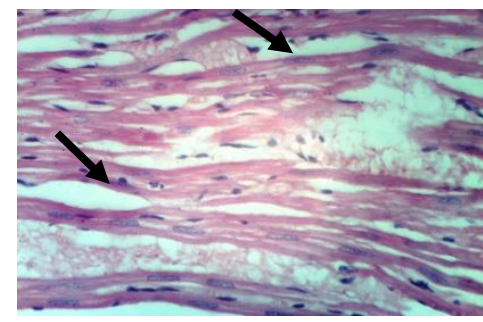

Fig. (6): Heart of rat from group 4 showing intermuscular oedema.

\section{2-Morphologic changes of rat liver stained with hematoxylin and eosin:}

Representative liver sections stained with hematoxylin and eosin in each group are shown in Figure (7:12). The liver in the control rat of group Co. (-) (Fig. 7) showing the normal histological structure of hepatic lobule The morphologic features of the liver in the rats of G 2 and G 3 were closed to that of the control rats group Co. (-), which indicated a similar preventive effect of mixture herb in this experimental model. While the Liver of rats from group 4 showing Kupffer cells activation and steatosis of hepatocytes. The Fatty liver and crown-like structures are one of the well-known features resulting from feeding rats with HFD due to increased accumulation of fatty acids in the liver and reduced oxidation of free fatty acids (Jang and Choung, 2013; Tinkov et al., 2014). Adipose tissue of obese animals and humans is usually in filtered by macrophages that are arranged around dead adipocytes, forming characteristic crown-like structures (Murano et al., 2008).

El-shiekh et al. (2018) demonstrated that the histopathological examination showed macrovesicular steatosis in the liver and an increase in the number of crown-like structures in adipose tissue of the HFD group, resulting in liver and adipose tissue weight gains. However, S. argel supplementation markedly attenuated the extent of steatosis and decreased the number of crown like structures, suggesting that Argel may regulate lipid storage along with high fats in the diet and undoubtedly reduce significantly liver and adipose weight gains, as well as, body fat expressed by Lee index. As well as, improvement in 
liver histopathology which further reinforced the serum biochemical findings. This indicated the curative action of $S$. argel towards the fatty liver and obesityinduced insulin resistance caused by the HFD.

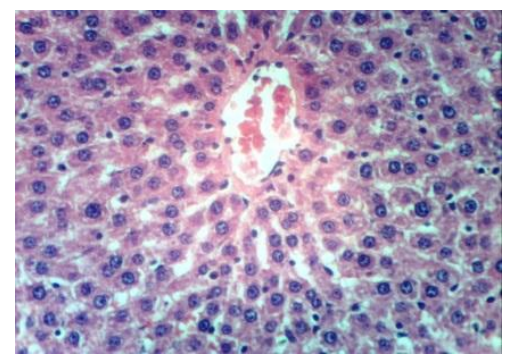

Fig. (7): Liver of rat from group Co(-) showing the normal histological structure of hepatic lobule.

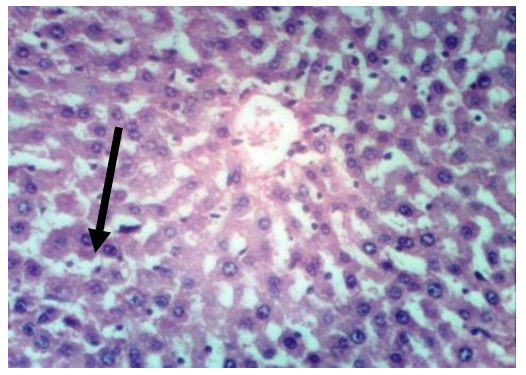

Fig. (9): Liver of rat from group 1 showing Kupffer cells activation.

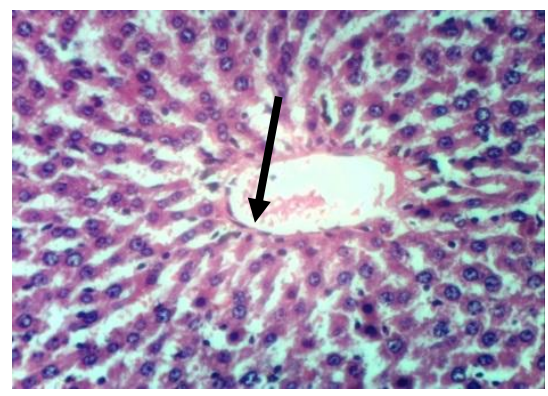

Fig. (11): Liver of rat from group 3 showing slight Kupffer cells activation

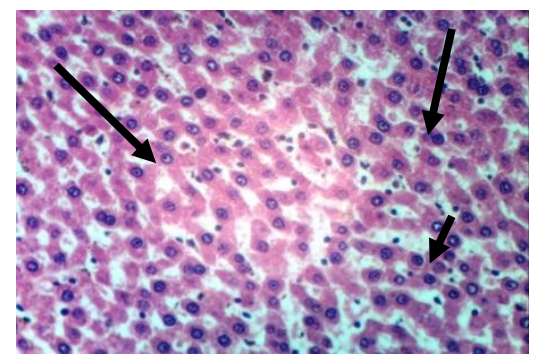

Fig. (8): Liver of rat from groupCo(+) showing Kupffer cell activation with few leucocytes in hepatic sinusoids.

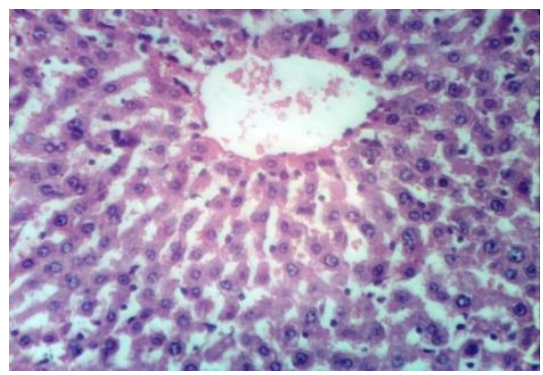

Fig. (10): Liver of rat from group 2 showing Kupffer cells activation.

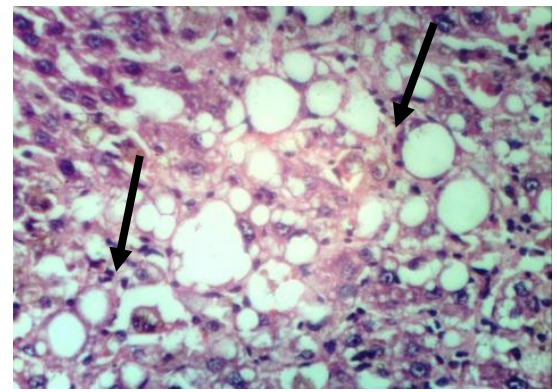

Fig. (12): Liver of rat from group 4 showing Kupffer cells activation and steatosis of hepatocytes

\section{3-Morphologic changes of rat kidney stained with hematoxylin andeosin:}

Representative kidney sections stained with hematoxylin and eosin in each group are shown in Figure (13: 18), kidneys of rats from group co (+) revealed congestion of renal blood vessel, atrophy of glomerular tuft with distension of Bowman's capsule and focal inflammatory cells infiltration (Fig. 11).On the other hand, the kidney of rats in groups1,2,3 and 4 showing the normal histological structure of renal parenchyma was closed to that of the control rats 
group Co. (-), which indicated a similar preventive effect of mixture herb in this experimental model.

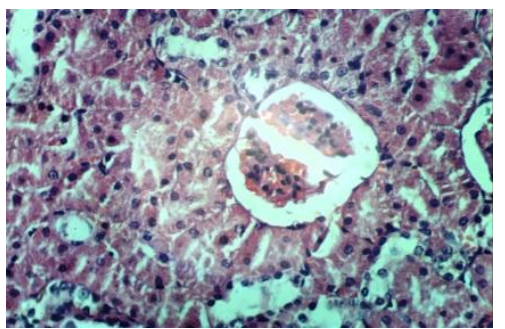

Fig. (13): Kidney of rat from group co (-) showing the normal histological structure of renal parenchyma.

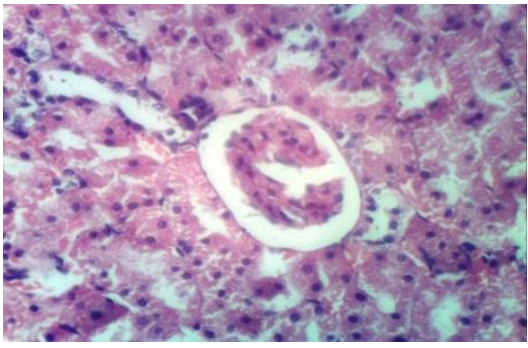

Fig. (15): Kidney of rat from group 1 showing no histopathological changes.

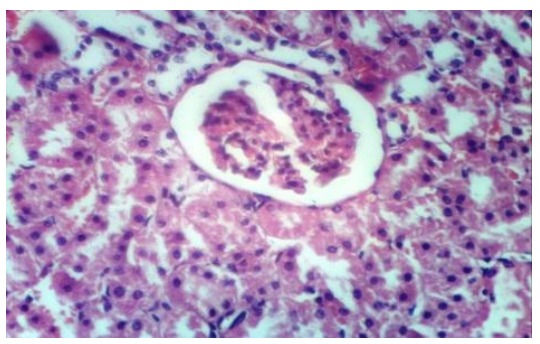

Fig. (17): Kidney of rat from group 3 showing no histopathological changes.

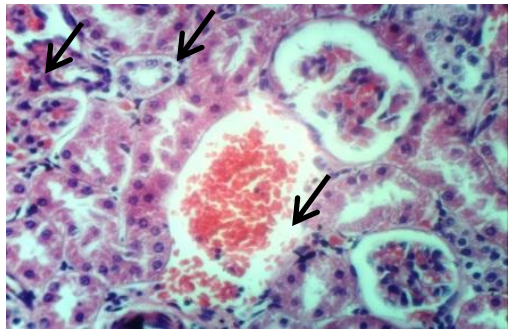

Fig. (14): Kidney of rat from group co (+) showing congestion of renal blood vessels.

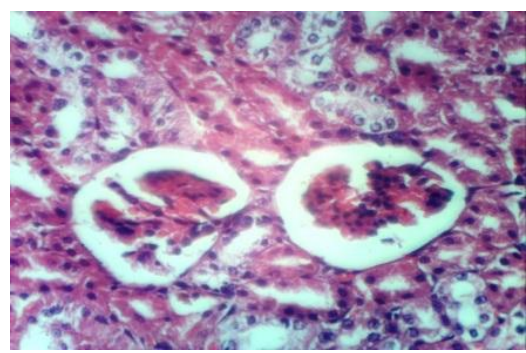

Fig. (16): Kidney of rat from group 2 showing no histopathological changes.

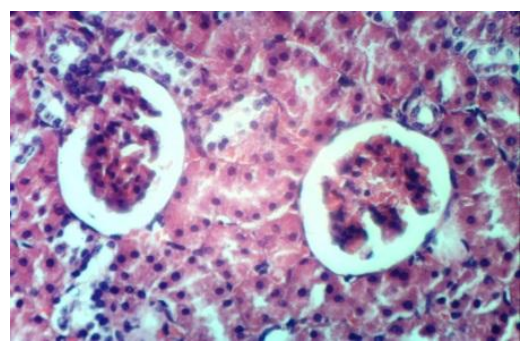

Fig. (18): Kidney of rat from group 7 showing no histopathological changes.

\section{CONCLUSION}

From the results, it could be concluded that the leaves from mallow (Malvaparviflora), white tea (Camellia Sinensis) and senna (Cassia Angustifolia) had contained rich amounts polyphenolic, minerals, fiber, and total carbohydrates from the literature. Based on our results, we conclude that the intake of mixture herbs succeeded in reducing body weight without adverse effect, therefore high fat intake. Therefore, these herbs led to improvement the lipids profile, liver and kidney functions in rats' different groups fed on the mixture these herbs at 10 and $20 \%$ and also, the extract from these herbs in the mixture taken orally at level 100 and $200 \mathrm{mg} / \mathrm{kg}$ rat/ day led to improve the previous parameters in the obesity rats, these means these herbs as therapy for 
obesity. Moreover, the results from the histological experiment showed that the obesity rat organs as heart, liver, and kidney were confirmed the previous results and preservation of the different organs. 


\section{REFERENCES}

A.O.A.C., (2006): Official Methods of Analysis. 18th Edition, Association of Official Agricultural Chemists.Washington D.C., USA.

Abdalla, M., M., A. and Yousef, M., H., A. (2016): Effect of Cooking on Nutritive Value of Jew's Mallow (Corchoru solitorius L.) and Mallow (Malva parviflora L.) Leaves', Alexandria Journal of Food Science and Technology, 13(2), pp. 1-10. DOI: 10.12816/0038408.

Abdel-Sattar, E., Mehanna, E.T., El-Ghaiesh, S.H., Mohammad, H.M.F., Elgendy, H.A. and Zaitone, S.A. (2018): Pharmacological Action of a Pregnane Glycoside, Russelioside B, in Dietary Obese Rats: Impact on Weight Gain and Energy Expenditure. Front. Pharmaco 1.9, 990. https://doi.org/10.3389/fphar.2018.00990.

Afolayan AJ, Aboyade OM, Adedapo AA, and Sofidiya MO. (2010): Anti inflammatory and analgesic activity of the methanol extract of Malva parviflora Linn. (Malvaceae) in rats. Afr. J. Biotech.; 9:1225-29.

Ajeet S., N. (2017): Ethnomedicinal, Antimicrobial and Pharmacological aspects of Malva parviflora L. inn.: A review, The Journal of Phytopharmacology; 6(4): 247-250.

Anderson R.A. and Polansky M.M. (2002): Tea enhances insulin activity. J Agric Food Chem; 50:7182-6.

Bach A.C., Ingenbleek Y., Frey A. (1996): The usefulness of dietary mediumchain triglycerides in body weight control: fact or fancy? J. Lipid Res, 37: 708-726.

Badimon, L.; Vilahur, G. and Padro, T. (2010): Nutraceuticals and atherosclerosis: Cardiovasc. Ther. 28, 202-215. [CrossRef] [PubMed]

Balasankar, D., Vanilarasu, K., Selva Preetha, P., Rajeswari, S., Umadevi, M. and Bhowmik, D. (2013): Senna - A Medical Miracle Plant, Journal of Medicinal Plants Studies, 1(3):41-47.

Barham, D. and Trider, P. (1972): Enzymatic determination of serum uric acid. Analst, 97: 142-145.

Belfied, A. and D. M. Goldberg, (1971): Human serum glucose-6-phosphatase activity: confirmation of its presence and lack of diagnostic value. Enzyme, 12:561-265.

Bjorston, A. R., Crankshaw, D. P., Morgan, D. J and Prideaux, P. R. (2007): Clinical Chemistry. Department of Surgery, Royal Melbourne 
Hospital, University of Melbourne, Victoria, 3050.

Bouriche H., Meziti H., Senator A. and Arnhold J. (2014): Antiinflammatory, free radical-scavenging, and metal-chelating activities of $\mathrm{M}$. parviflora." Pharm Biol. May 19(6) 254-267.

Cameron, J.S. and Greger, R. (1998): Renal Function and Testing of Function. In: Oxford Textbook of Clinical Nephrology (Davison AM, Cameron JS, Grunfeld JP, Kerr DNS, Rits E, Winearl GC.(eds). Oxford University Press. 36 - 39.

Carleon, M. L. (1967): Histological technique 4th.edition. Oxford University Press, New York Toronto. p. 166,177,204, 212.

Chapman, D. G.; Castilla, R. and Campbell, J. A. (1959): Evaluation of protein in food. Method for the determination of protein efficiency ratio. Can .J. Biochem. Phsiol., 1: 679- 686.

Cheng OT. (2006): All teas are not created equal-Chinese green tea and cardiovascular health. Int J Cardiol, 108:301-8.

Constantinou, C.; Papas, A. and Constantinou, A. I. (2008): Vitamin E and cancer: An insight into the anticancer activities of vitamin $\mathrm{E}$ isomers and analogs. Inter. J. of Cancer, 123, 739-752.

Drury, R. A. and Wallington, E. A. (1980): Carlton's Histological Technique. 5th ed. Oxford University.

El- Sahar E. G. (2012) ${ }^{2}$ : Evaluation of the Effect of M. parviflora Extracts as a Natural Source of Antioxidants on Markers of Aging. Saudi Society Journal for Food \& Nutrition, (7) (1) (ISSN: 142-33).

Elbashir, S.M.I., Devkota, H.P., Wada, M., Kishimoto, N., Moriuchi, M., Shuto, T., Misumi, S., Kai, H. and Watanabe, T. (2018): Free radical scavenging, $\alpha$-glucosidase inhibitory and lipase inhibitory activities of eighteen Sudanese medicinal plants. BMC Complement.Altern.Med. 18, 282.https://doi.org/10.1186/s12906-018-2346-y.

EL-Sahar E. G. (2012) ${ }^{\mathbf{1}}$ : Effect of using herbal mixture extract and camellia Sinensis and on weight loss in overweight and obese humans as therapy for obesity. Journal of American Science 2012; 8(8): 51-60]. (ISSN: 15451003). http://www.americanscience.org.

EL-Sayeda, G. E. and Abor M. M. (2017): Therapeutic Effect of Bread Fortified with White tea on Experimental Induced Diabetes Rats with Study Chemical and Sensory evaluation of bread International Journal of Applied and Pure Science and Agriculture (IJAPSA) 03, 3, 37-47. 
El-Shiekh, R.A., Al-Mahdy, D.A., Hifnawy, M.S. and Abdel-Sattar, E.A. (2018): In-vitro screening of selected traditional medicinal plants for their anti-obesity and anti-oxidant activities. S. Afr. J. Bot. 123, 43-50. https://doi.org/10.1016/j.sajb..01.022.

El-Shiekh, R.A., Al-Mahdy, D.A., Mouneir, S.M., Hifnawy, M.S. and Abdel-Sattar,E.A. (2018): Anti-obesity effect of argel (Solenostemmaargel) on obese rats fed a high-fat diet, Journal of Ethnopharmacology.doi: https://doi.org/10.1016/j.jep..111893.

Farhan H, Rammal H, Hijazi A. and Badran B. (2012): Preliminary phytochemical screening and extraction of polyphenol from stems and leaves of a Lebanese plant Malvaparviflora L. Int J CurrPharma Res. 2012; 4:55-59.

Fendewaid, W. T. (1972): Determination of HDL. Clin. Chem. 18:499-503.

Friedman, M.; Yeunkim, S.; Junglee, S.; Gyeong- philhan, G.; Sookhan, j.; Ranglee, $K$ and Kozukue, N. (2005): Distribution of Catechins, Theaflavins, Caffeine, and Theobromine in 77 Teas consumed in the United States. Food Chemistry and Toxicology. Vol. 70; (9): 550-559.

George, R. K. (2009): Biochemistry Laboratory. Philadelphia www.jbc.org.

Gordon, T. and Amer, M. (1977): Determination of HDL. J. Med. 63:707709.

Grela E.R. (2000): Influence of herbs mixture in pips feeding on performance and some lipid parameters in blood back fat Annales - Universitatis - Mariae - Curie - Sklodowska - Sectio - EE - Zootechnica. 18: 243 - 250.

Hartz A.J., RupleyJ.r, D.C., Kalkhoff R.D. and Rimm A.A. (1983): Relationship of obesity to diabetes: influence of obesity level and body fat distribution. Prev. Med., 12: 351-357.

International Legume Database and Information Service (ILDIS) (2005): Genera Cassia and Senna. Version 10.01, November 2005.

Jaffer, A. R.; Babb, J. and Movahed, A. (2004): Optimal management of hyperlipidemia in primary presentation of cardiovascular disease. Int. J. Cardiol., 97(3):355-366.

Jang, W.S. and Choung, S.Y., (2013): Antiobesity effects of the ethanol extract of Laminaria japonica Areshoung in high-fat-diet-induced obese rat. Evidence-based Complement. Altern. Med., 492807.https://doi.org/10.1155/2013/492807. 
Jia X, Han C. and Chen J. (2002): Effects of tea on preneoplastic lesions and cell cycle regulators in rat liver. Cancer Epidemiology Biomarkers and Prevention.; 11(12):1663-1667.

Kamel, M. (2003): Acylated phenolic glycosides from Solenostemmaargel. Phytochemistry, 63: 1247 - 1250. Mohamed, E., Amani S., Mounerah, R. and Reham, M., 2012.Antimicrobial activities of Saudi Arabian desert plants.Phytopharmacology; 2:106 - 113.

Kerim, R. A., Elisa, Á. A., Lucía, B. J., Martín, R. C., Arcelia, G. T., Javier, R. E. and David, R. (2017): Impact of Cassia acutifolia Infusion on Glucose Levels in Obesity and Diabetes Rat Model. Journal of pharma co puncture, 20 (3), 201-206. doi:10.3831/KPI.2017.20.023.

Lambert, J. D. (2009): Hepatotoxicity of high oral dose -epigallocatechin-3gallate in mice. Food and Chemical Toxicology, v. 48, n. 1, p. 409416,.http://dx.doi.org/10.1016/j.fct..10.030.

Larsson B., Bjorntorp P. and Tibblin G. (1981): The health consequences of moderate obesity. Int. J. Obese., 5: 97-116.

Lee, R. and Nieman, D. (1996): Nutritional Assessment; $2^{\text {nd }}$ ed Mosby Missouri, USA.

Lílian Gonçalves Teixeira; Priscilla CeciLages and Tatianna Lemos Jascolka (2012): White tea (Camellia sinensis) extract reduces oxidative stress and triacylglycerols in obese mice- Food Science and Technology ISSN 0101-2061On-line version ISSN 1678-457X.

Mansour, H.A., Newairy, A.S., Yousef M.I. and Sheweita S.A. (2002): Biochemical study on the effects of some Egyptian herbs in alloxan-induced diabetic rats. Toxicology, 170: 221-228.

McKay D.L. and Blumberg J.B. (2002): The role of tea in human health: an update. J Am CollNutr 2002; 21:1-13.

Milagro F.I, Campio'n J. and Martı'nez A. (2006): Weight gain induced by high-fat feeding involves increased liver oxidative stress. OBESITY, 14 (7): 1118-1123.

Moderno P.M., Carvalho M. and Silva B.M. (2009): Recent patents on Camellia sinensis: Source of health promoting compounds. Recent Pat.Food Nutr. Agric.; 1: 182-192. doi: 10.2174/2212798410901030182. [PubMed] [CrossRef] [Google Scholar].

Murano, I., Barbatelli, G., Parisani, V., Latini, C., Muzzonigro, G., Castellucci, M. and Cinti, S. (2008): Dead adipocytes, detected as crown- 
like structures, are prevalent in visceral fat depots of genetically obese mice. J. Lipid Res. 49, 1562-1568. https://doi.org/10.1194/jlr.M800019-JLR200

Murase T., Aoki M., Wakisaka T., Hase T. and Tokimitsu I. (2002): Antiobesity effect of dietary diacylglycerol in C57BL/6J mice: dietary diacylglycerol stimulates intestinal lipid metabolism. J. Lipid Res, 43: 13121319.

Naganna, B. (1989): Plasma Proteins. In: Textbook of Biochemistry and Human Biology. G.P. Tawlar, L M. Scrivastava and K.D. Moudgils (eds). Second edition.Prentice-hall of India Private Ltd. 172 - 181.

Nemani, H.; Putcha, U.; Boindala, S.andNappanveettil, G. (2011): Obesityassociated pathophysiological \& histological changes in WNIN obese mutant rats. Indian, J. Med. Res. 134, 9, 330-340.

NIHP. (1987): National Institute of Health Publication. Detection, Evaluation and Treatment of High Cholesterol in Adult; No.88:292.

Nomura, S. (2008): Tea catechins enhance the mRNA expression of uncoupling protein 1 in rat brown adipose tissue. The Journal of NutritionalBiochemistry, V. 19, n. 12, p. 840-7, 2008.http://dx.doi.org/10.1016/j.jnutbio.2007.11.005.

Patton, C. H. and Crouch, S. R. (1977): Enzymatic colorimetric method to determine urea in serum. Anal. Chem., 49: 464-469.

Pellizzon M., Buison A., Ordiz F., Santa L. and Jen L. (2002): Effects of dietary fatty acids and exercise on body-weight regulation and metabolism in rats. Obese Res, 10: 947-955.

Perez R. and Gutierrez M. (2012): Evaluation of the hypoglycemic activity of the leaves of M. parviflora in streptozotocin-induced diabetic rats, Food Funct., 3, 420-427.

Phung, O. J. (2010): Effect of green tea catechins with or without caffeine on anthropometric measures: a systematic review and meta-analysis. The American Journal of Clinical Nutrition, v. 91, n. 1, p. 73-81.

Posadzki P, Watson L. and Ernst E. (2013): Herb-drug interactions: an overview of systematic reviews.Br J. ClinPharmacol. 2013 Mar; 75(3):60318.

Reitman, S. and Frankel, S. (1957): A calorimetric method for the determination of serum glutamic-oxaloacetic and glutamic -pyrovate transaminase. Am. J. Clin. Path. P.p. 28-56. 
Robert B., Saper M. D., David M., Eisenberg M. D., Russell S. and Phillips M.D. (2004): Common Dietary Supplements for Weight Loss, Harvard Medical School, Boston, Massachusetts, American Family Physician American Academy of Family Physicians. November 1 (70), 9-11.

Rosa Martha Perez Gutierrez (2012): Evaluation of hypoglycemic activity of the leaves of Malva parviflora in streptozotocin-induced diabetic rats. Food Funct. Apr; 3(4):420-7. doi: 10.1039/c2fo10153j. Epub 2012 Jan 30.

DOI: $10.1039 / \mathrm{c} 2$ fo10153j

SaitByul Park and YeongShik Kim (2015): Simultaneous separation of three isomeric sennosides from senna leaf (Cassia acutifolia) using counter-current chromatography -journal of separation science, Volume38, Issue20.

Schirmeister, J. (1964): Creatinine standard and measurement of serum creatinine with picric acid. Dtsch. Med. Wschr., 89:1018-1022.

Schone F., Vetter A., Hartung H., Bergmann H., Biertümpfel A., Richter G., Müller S. and Breitschuh G. (2006): Effects of essential oils from fennel (Foeniculia etheroleum) caraway (Carvia etheroleum) in pigs. J Anim Physiol. Anim. Nutr. (Berl), 90:500-10.

Seeram N.P., Henning S.M., Niu Y., Lee R., Scheuller H.S., Heber D. (2006): Catechin and caffeine content of green tea dietary supplements and correlation with antioxidant capacity. J. Agric. Food Chem. 2006; 54:15991603.doi: 10.1021/jf052857r. [PubMed] [CrossRef] [Google Scholar].

Shale T. L., Strik W. A. and Staden J. V. (2005): Variation in antibacterial and anti-inflammatory activity of different growth forms of M. parviflora and evidence for synergism of the anti-inflammatory. Compounds. Journal of Ethnopharmacology, 96(1/2):325-330.

Shayoub, M., Haj, E., Makawy, A., Rasha, R. Mona, A. (2013): Adverse reaction of Solenostemmaargel leaves, extraction and alkaloids tablets administered to patients. Global. J. Trad. Med. Sys. 2(1): 14-18.

SPSS. (1998): Statistical Package for Social Science, Computer Software; ver.10 SPSS Company. London, UK.

Taj Al-Deen.A and Al-Naqeeb, G (2014): Hypoglycemic effect and in vitro antioxidant activity of methanolic extract from Argel (Solenostemma Argel) plant - International Journal of Herbal Medicine; 2 (2): 128-131.

Tietz, N. W. (1986): Text Book of Clinical Chemistry. P.796.Saunders, W. B. Co., London-Philadelphia. 
Tinkov, A.A., Nemereshina, O.N., Popova, E. V., Polyakova, V.S., Gritsenko, V.A. and Nikonorov, A.A., (2014): Plantago maxima leaves extract inhibits adipogenic action of a high-fat diet in female Wistar rats. Eur. J. Nutr. 53, 831-842. https://doi.org/10.1007/s00394-013-0587-6.

Tunapong, W., Apaijai, N., Yasom, S., Tanajak, P., Wanchai, K. ( 2018) Chronic treatment with prebiotics, probiotics and synbiotics attenuated cardiac dysfunction by improving cardiac mitochondrial dysfunction in male obese insulin-resistant rats. Eur. J. Nutr. 57, 2091-2104. 143147.https://doi.org/10.1007/s00394-017-1482-3.

Ulbricht, C., Conquer, J., Costa, D., Hamilton, W., Higdon,E.R., Isaac, R., Rusie, E., Rychlik, I., Grimes Serrano, J. M., Tanguay-Colucci, S., Theeman, M. and Varghese,M., (2011 ): An evidence-based systematic review of senna (Cassia senna). J. Dietary Suppl. 8, 189-238.

Vinchi, F., Gastaldi, S., Silengo, L., Altruda, F. and Tolosano, E. (2008):Hemopexin prevents endothelial damage and liver congestion in a mouse model of heme overload. Am. J. Pathol. 173(1): 289-299.

Wang X. and Bunkers G. j. (2000): potent heterologous antifungal proteins from cheeseweed (M. parviflora). Biochemical and Biophysical Research Communications, 279(2):669-673.

Wiseman S.A. Balentine, D.A. and Frei B. (1997): Antioxidants in tea, Crit. Rev. Food Sci. Nutr. 37- 705-718.

Wolever, T. M. S.; Elizabeth, B.; Tsihliasa, E. B.; Michael, I. and NgocAnh L. M. (2003): Long-term effect of reduced carbohydrate or increased fiber intake on LDL particle size and HDL composition in subjects with type 2 diabetes. Nutrition Research, 23: 15-26.

Young and Pestaner. (1975): Determination of triglycerides. Bincon diagnostics, Germany. Ann. Clin.. Biochem. 21:25. 


\section{ABSTRACT \\ A comparative study of the effectiveness of some herbs and medicinal plants in therapy obesity in experimental rats}

Obesity is considered a big problem that has a huge effect on health and production. The present investigation aims to determine the effect of using a mixture of natural herbs (Mallow, white tea, argel and Senna) and it's aqueous extract on weight loss in obese rats and compare between them, A total of 30 rats, divided into two main groups: the first, negative control group Co. $(-)(n=5)$, fed basal diet. The second group $(n=25)$ fed high- fat diet (containing basal diet $+20 \%$ tallow $+1 \%$ cholesterol $+0.02 \%$ bile salt) to reach a weight of $225 \mathrm{~g}$ to $240 \mathrm{~g}$ and it took about two months to get obese rats. This group was divided into five subgroups each group ( $n=5)$ : group positive control co. (+) fed high-fat diet only, G (1) and G (2) fed a high-fat diet plus 5\% and $10 \%$ mixture herbs respectively. G (3) and G (4) fed a high-fat diet plus taken orally 100 and $200 \mathrm{mg} / \mathrm{kg}$ for rat/ day respectively from the extract were taken orally. Food intake recorded daily, body weight recorded weekly, After 8 weeks of body weight gain and feed efficiency rate total cholesterol (TC), triglycerides (TG), HDL-C and LDL-C were determined, in addition to serum glucose, liver and kidney function. The histopathological changes of the heart, liver and kidney were evaluated. SPSS, one way ANOVA was used to analyze the results. The results indicated that all experimental groups gave a significant decrease in body weight and feed efficiency ratio, G (3 and 4) showed the highest significant decrease compared to group Co (-) and Co. (+). Found the best moral improvement in glucose, total cholesterol, LDL-C and HDL-C in G4 taken orally the aqueous extract from the herbal mixture at $200 \mathrm{mg} / \mathrm{kg}$ rat/ day. Level of ALT in G1, G2, G3 and G4 had significantly improved. Found significant improvement in AST in groups G1 and G2, ALK had significantly improved in groups G1, G2 and G3. At the end of the experiment, total protein in G1, G2, G3 and G4 had significant increase at $(p<0.05)$ compared with control negative and positive groups, but there were no significant differences in experimental groups in albumin and bilirubin, uric acid showed significant increase in G1, G2, G3 and G4 at ( $\mathrm{p} \leq$ 0.01) when compared with control negative and positive groups there was also improvement in G2, G3 and G4. The results from the histological experiment showed that the obesity rat organs as heart, liver, and kidney were confirmed the previous results and preservation of the different organs. It could be concluded and recommended that the intake of mixture herbs succeeded in reducing body weight without adverse effect, therefore high fat intake. This herbs improvement the parameters of lipid profile, liver and kidney functions in the obesity rat groups.

KEYWORDS: herbs; medicinal plants, blood lipids, Cholesterol, glucose, HDL-C, LDL-C, Hypercholesterolemia, Liver, Heart, body weight gain. 


\section{دراسة مقارنة لفعالية بعض الأعثاب والنباتات الطبية في علاج السمنة لدى فئران التجارب ملخص البحث}

تعتبر السمنة مشكلة خطيرة تؤثر بشكل كبير على الصحة و الإتناج ، يهدف البحث البحث الحالي إلى در اسة تأثير

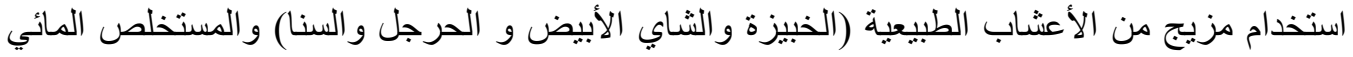

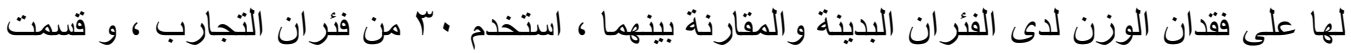

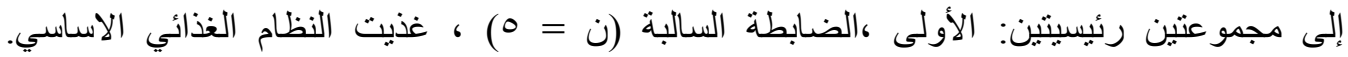

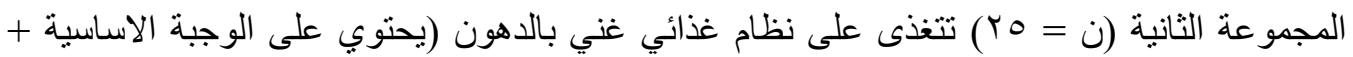

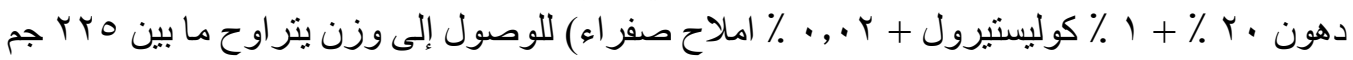

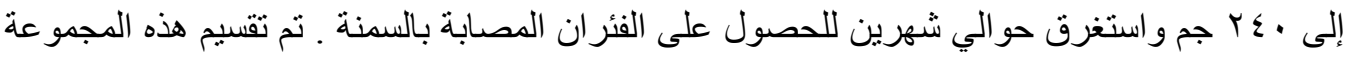

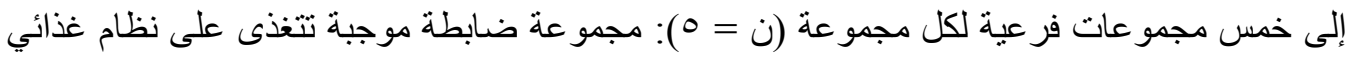

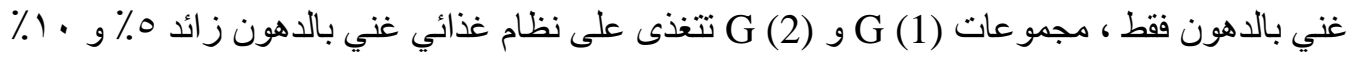

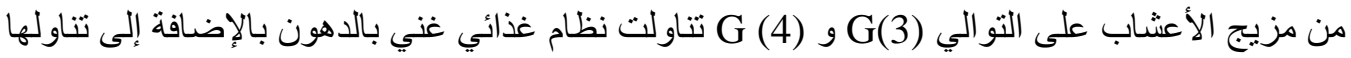

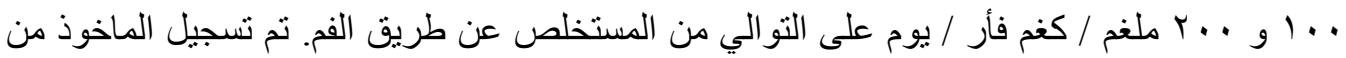

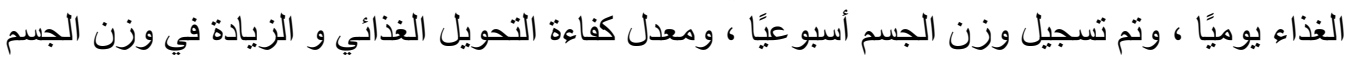

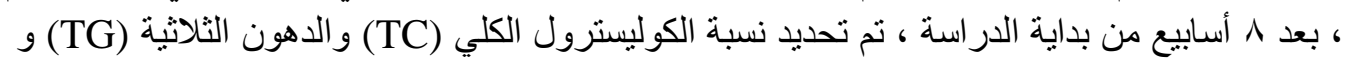
LDL-C وHDL-C

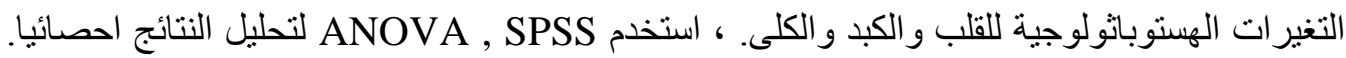

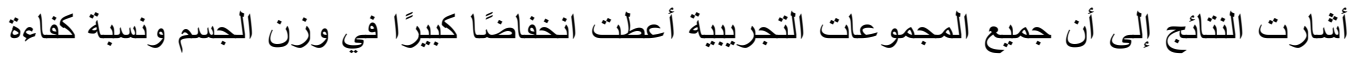

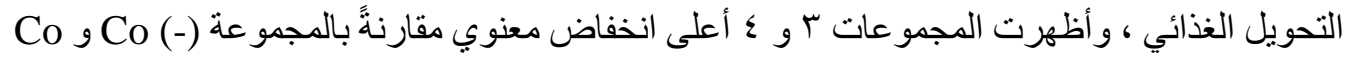

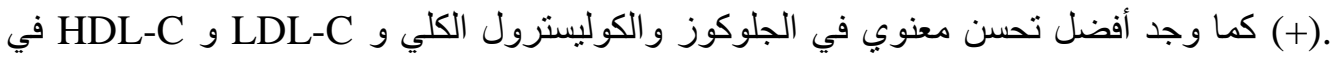

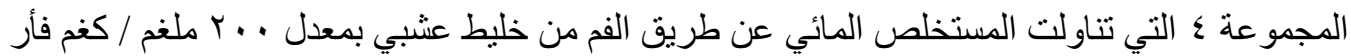

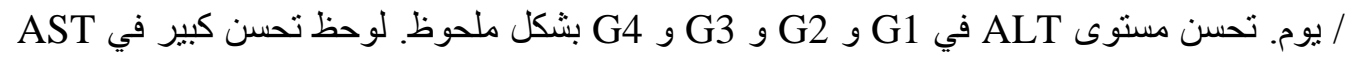

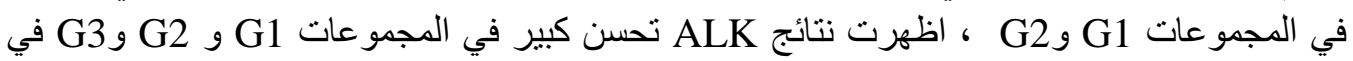

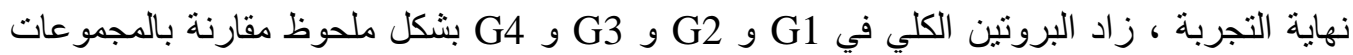

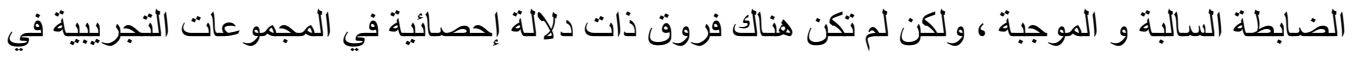

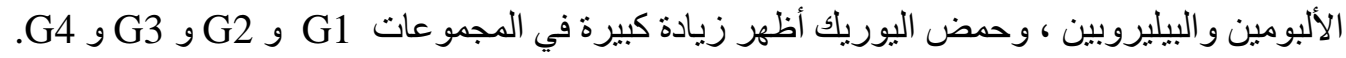

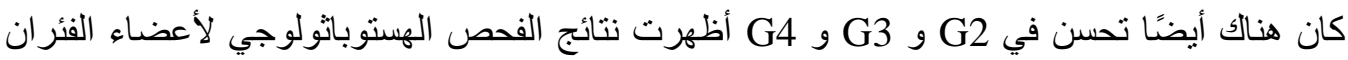

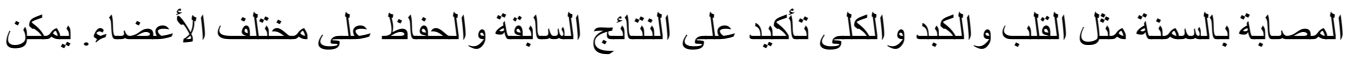

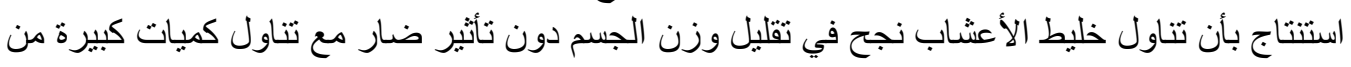

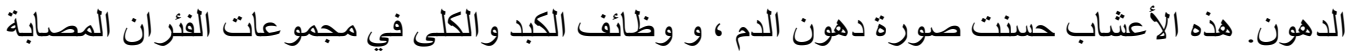

